\title{
REVERSE SURAL ARTERY FASCIOCUTANEOUS FLAP IN SOFT TISSUE RECONSTRUCTION IN LOWER EXTREMITY
}

Suresh Pandey ${ }^{1, *}$, Suraj Bidary ${ }^{1}$

${ }^{1}$ Department of Orthopaedics, College of Medical Sciences, Chitwan, Nepal

Received: 2 Jul, 2020
Accepted: 24 Sept, 2020
Published: 27 Sept, 2020
Key words: Ankle; Soft tissue reconstruction; Sural ar-
tery flap.
*Correspondence to: Suresh Pandey, College of Medical
Sciences, Chitwan, Nepal.
Email: drsuresh.orthonepal@gmail.com
Citation
Pandey S, Bidary S. Reverse sural artery fascio-
cutaneous flap in soft tissue reconstruction in
lower extremity. Journal of Chitwan Medical Col-
lege.2020;10(33):84-7.

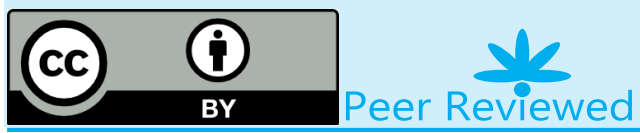

INTRODUCTION

Soft tissue defect in the distal third leg, ankle and heel area poses a great challenge for an Orthopaedic surgeon who routinely has to deal with complex fractures or soft tissue loss around these regions. The most common cause of soft tissue loss in such regions is the sequelae of trauma. Other causes are infection, diabetic foot and cutaneous malignancy.

Soft tissue reconstruction in the distal third leg, ankle and heel region has limited choice. Free microvascular flap can be a good choice but needs expertise and microvascular experience. Local rotation flap has limited utility due to tight tissue around. Distal based sural artery pedicle flap is the most suitable and routinely used choice to cover such defect. ${ }^{1}$ Masquelet first described this flap in 1992 and it has been used extensively with high success rate since then. ${ }^{2}$ Hasegawa et al in their study of sural artery flap to cover the defect around ankle showed good result in all the cases. ${ }^{3}$ Li-You et al had shown good healing in the all the cases of traumatic defect of heel with sural artery flap in their case series. ${ }^{4}$ Similar results were found in the study of Talukdar et al in their study of sural artery flap in covering defect after tumor surgery around the ankle. ${ }^{5}$
Limited studies are available from our country regarding demographics and result of such flap surgery. The aim of the present study was to analyze the demographic parameters and functional result of distal based sural artery flap in soft tissue reconstruction in distal leg, ankle and heel.

\section{METHODS}

This was a retrospective study of 12 cases of sural artery based fasciocutaenous flap performed by single orthopaedic surgeon from January 2015 to December 2019 for the soft tissue reconstruction in distal third leg, ankle and heel. Indications for the surgery was exposed ankle or calcaneus, loss of heel, exposed tendons around calcaneus, nonresolving ulcer around the ankle and wound defect after tumor surgery. Inclusion criteria was wound defect at ankle, heel and distal third leg not amenable for primary closure or grafting. Exclusion criteria was case operated at some other centre, peripheral vascular disease and uncontrolled diabetes Mellitus. Case record from medical record sections were studied and data was entered in excel for demographics, intra and post-operative details. Final follow up was done at minimum of 6 months after index surgery to assess limb function, recurrence of tumor or development of sore. Data was entered into Excel chart and results 
were analyzed using SPSS version 20 software. Consent for the study was taken from the institutional review board.

The anatomic basis for reverse sural artery flap is due to the communication of perforators from the peroneal artery $5-7 \mathrm{~cm}$ above the lateral malleolus with the descending superficial sural artery, branch of popliteal artery.

Patient, under spinal or general anesthesia, was operated on prone position for the ease of flap marking and raising. After wound debridement, size of the defect was marked with gauze and outline of the flap over the calf was done with the same gauze. Vascular marking was marked on the skin along the line joining midpoint of popliteal crease and midpoint between lateral malleolus and midline of tendoachilles. Upper limit of the flap was kept between upper and middle third junction in general (up to popliteal crease as maximum upper limit) and lower limit $7 \mathrm{~cm}$ proximal and posterior to tip of lateral malleolus. ${ }^{3,6,7}$ But depending upon the wound size defect, proximal extent of flap was kept flexible. Flap size and shape was decided by wound size and shape and incision was kept $1 \mathrm{~cm}$ bigger than the wound size to take care of tissue contraction after raising flap. Incision was started from proximal part with identification of small saphenous vein in subcutaneous plane and sural nerve beneath the fascia between grooves of two head of gastrocnemius muscle. No intraoperative Doppler was used as this facility was not available.

Superficial sural artery along with sural nerve were ligated and divided proximally and temporary stitch with fascia and skin was taken. Sharp dissection was done and flap was raised from proximal to distal aiming to keep the small saphenous vein, sural nerve and artery at the center of designed flap. Distal limit of dissection was $7 \mathrm{~cm}$ proximal from tip of lateral malleolus which is the desired pivot point of the flap. Procedure was done under tourniquet control and once flap was raised, tourniquet was deflated to check the vascularity at the flap margin. Flap was stitched with the margin of skin at recipient site with- out tension with 3-0 prolene and skin graft was done in all the cases at donor site defect. Dressing was done carefully with good padding. Pressure or tension at the flap site and pedicle was avoided in the intra or post-operative phase by asking patient to lie down on prone or lateral position or keeping ankle and heel off the bed.

Flap was inspected daily for its viability, margin necrosis or infection with color, bleeding, consistency and warmth. Dressing was done on $2^{\text {nd }}, 4^{\text {th }}$ and $6^{\text {th }}$ postoperative day. Suture was removed at 2 weeks and division and in setting of the flap was done at 3 weeks in 9 cases. Grafted area and donor site dressing was done on $5^{\text {th }}$ and $10^{\text {th }}$ postoperative day and left open. Follow up was done at 1, 6, 12 months and then yearly to assess the functional ability and any local or systemic complications.

\section{RESULTS}

There were total of 12 patients with 10 males and 2 females with mean age of 39 (range, 25-52) years who were managed with distal based sural artery pedicle flap. Demographic and treatment details of the patients have been given in the Table 1.

The mean duration of symptoms was 16.5 month (range, 0.5$48)$ and median duration of follow up was 18 months $(Q 1=23$, $\mathrm{Q} 3=23.75$ ). Average operatve time was 95 minutes with range 65-120 minute. All flap healed at 3 weeks except one who had complication with complete flap necrosis.

The most common reason for flap reconstruction was RTA with soft tissue loss, $58.3 \%(n=7)$ followed by cutaneous malignancy $25 \%(n=3)$ and infection $17.6 \%(n=2)$. The biggest size of the wound was $17 \times 8 \mathrm{~cm}$ and the smallest size was $8 \times 5 \mathrm{~cm}$. Most of the wound defects were at heel $41.6 \%(n=5)$ followed by tendoachilles $25 \%(n=3)$, ankle or malleolar region $16.6 \%(n=2)$ and distal $3^{\text {rd }}$ leg $16.6 \%(n=2)$.

Table 1: Demographic details, treatment, results and complications of the 12 patients

\begin{tabular}{|c|c|c|c|c|c|c|c|c|c|c|}
\hline Case & Age & Sex & Cause & $\begin{array}{c}\text { Symptom duration } \\
(\mathbf{m t h})\end{array}$ & Site & $\begin{array}{c}\text { Size of } \\
\text { wound }(\mathbf{c m})\end{array}$ & Inf & $\begin{array}{c}\text { Margin } \\
\text { necrosis }\end{array}$ & FU (mth) & $\begin{array}{c}\text { Operative } \\
\text { time (min) }\end{array}$ \\
\hline 1 & 38 & M & RTA & 0.5 & Heel & $17 \times 8$ & No & No & 48 & 90 \\
\hline 2 & 46 & M & SCC & 48 & TA & $8 \times 10$ & No & No & 23 & 80 \\
\hline 3 & 25 & M & RTA & 4 & Ankle & $12 \times 7$ & No & No & 6 & 120 \\
\hline 4 & 48 & F & Infn & 52 & TA & $8 \times 6$ & No & No & 18 & 110 \\
\hline 5 & 40 & F & Melanoma & 24 & Heel & $12 \times 8$ & No & No & 6 & 112 \\
\hline 6 & 52 & M & SCC & 40 & Heel & $14 \times 6$ & No & No & 12 & 88 \\
\hline 7 & 32 & M & RTA & 1 & Heel & $12 \times 5$ & Yes & yes & 18 & 75 \\
\hline 8 & 37 & M & Infn & 20 & leg & $8 \times 6$ & No & No & 15 & 65 \\
\hline 9 & 52 & M & RTA & 3 & Ankle & $12 \times 8$ & No & No & 24 & 105 \\
\hline 10 & 27 & F & RTA & 1 & Distal leg & $10 \times 8$ & yes & yes & 32 & 120 \\
\hline 11 & 34 & M & RTA & 0.5 & Heel & $8 \times 5$ & No & Yes & 12 & 95 \\
\hline 12 & 44 & M & RTA & 7 & TA & $8 \times 6$ & No & No & 18 & 90 \\
\hline
\end{tabular}

Note: Infn, Infection; FU, Follow Up; mth, month; TA, Tendoachilles; RTA, Road Traffic Accident; SCC, squamous cell carcinoma; $M$, male; F, female) 
There was one complete flap necrosis over the heel defect which was later managed with skin grafting. Cause of flap failure was probably tension on the pedicle or poor technique of flap elevation. Two cases had marginal patchy necrosis which got well with minor debridement. Two cases had superficial infection which got cured with antibiotics. Superficial infection and patchy margin necrosis were found in the same cases. There was no stiffness of the joint or any functional deficit. There was partial loss of sensation over the dorsolateral aspect of foot over the sural nerve distribution area but they were not symptomatic. There was normal gait and range of motion at ankle in all the cases.

\section{DISCUSSION}

Resurfacing of soft tissue defect over distal third leg, ankle and heel region becomes challenging to an orthopedic surgeon who are not well versed with different types of flap reconstruction. Sural artery based reverse flap is commonly used and reliable fasciocutaenous pedicle flap option to cover the defect in the distal third leg, ankle, heel and foot region of varied etiology. ${ }^{8-11}$ Advantages of this surgery are relatively easy technique, use of varying size, longer arc of rotation and consistently higher satisfactory result. The major concern of all the flap surgery is chance of necrosis due to loss of vascular supply.

This flap as described originally by Masquelet in 1992 has been widely used..$^{12}$ The basis for the survival of this flap is due to the communication of perforators from the peroneal artery $5-7 \mathrm{~cm}$ above the lateral malleolus with the superficial sural artery which is the descending branch of popliteal artery. It is reliable as this flap includes fascia, adipose tissue and skin along with small saphenous vein, sural nerve and superficial sural artery in the mid axis of the flap which are reliable and guiding structures while raising flap. ${ }^{6}$ The arc of rotation can be longer and can be turned 180 degree. ${ }^{13,14}$ Pedicle can be fascioadipocutanous or adipofascial but with minimum width of pedicle being $4 \mathrm{~cm}$ to protect the perforators. Flap can reach the defect site either over the skin or through open defect or subcutaneous tunnel. If it has been applied over the intact skin, it is divided and inset after 3 weeks. Application through skin defect has advantage of no need for second procedure. Subcutaneous passage of flap is generally avoided because of increased risk of flap necrosis and failure due to tight tunneling. ${ }^{15}$
Sural artery based reverse flap is useful in the exposed bone and tendon in the distal third of leg, heel avulsion or loss of tissue due to trauma, diabetic foot, infection or after excision of the cutaneous malignancy such as squamous cell carcinoma and malignant melanoma. We had 5 cases of heel defect, 3 cases of exposed tendoachilles, 2 cases of soft tissue loss over malleolar region and distal tibia each. This study showed RTA as the most common cause of soft tissue defect constituting 58\% of the all causes which is in par with findings of other studies. ${ }^{16}$ Larrañaga et al In his study of sural artery flap after resection of melanoma around heel found flap survival in all the cases with no recurrence at 5 year follow up. ${ }^{17}$ Present study had 2 cases of SCC and 1 case of malignant melanoma and flap healed well in all the cases. Majority of the cases in our study was soft tissue defect after RTA and flap did well except one case of failure due to necrosis. Similar study done by Li-You et al had shown good result with survival of all the flaps done for post traumatic defect in the heel. ${ }^{4}$ Two cases of infection at leg and tendoachilles region in the present study requiring flap did well with satisfactory result. Al-Qattan et al had published similar results of sural flap surgery in 10 cases with infection and osteomyelitis with good healing in all the cases. ${ }^{18}$ Follmar et al in his study had found $83 \%$ of the survival of the flap. ${ }^{6}$ Margin necrosis in the flap has been found to be variable in different study ranging from $5 \%-30 \%$ which is comparable to complication rate of our study. ${ }^{3,5,16}$

Present study has got limited sample size. So, study involving larger sample size or multicentric study is recommended to validate the result of this study further.

\section{CONCLUSION}

Reverse sural artery fasciocutaenous flap is useful options for coverage of soft tissue defect in the distal third leg, ankle, heel and proximal foot area with satisfactory result in majority of the cases. It is technically easier and viable options in constrained set up also for soft tissue reconstruction around ankle due to traumatic, infective or tumorous causes.

\section{CONFLICT OF INTEREST: None}

\section{FINANCIAL DISCLOSURE: None}

\section{REFERENCES:}

1. Chen SL CT, Chou TD, Chen SG, Wang HJ. The distally based lesser saphenous venofasciocutaneous lap for ankle and heel reconstruction. Plastic and Reconstructive Surgery. 2002 Dec;110(7):1664-72. [DOI]

2. Masquelet AC RM, Wolf G. Skin island flaps supplied by the vascular axis of the sensitive superficial nerves: Anatomic study and clinical experience in the leg. Plast Reconstr Surg. 1992;89:1115-21. [DOI]

3. Hasegawa M TS, Katoh H, Esaki S. The distally based superficial sural artery flap. Plast Reconstr Surg 1994;93:1012-20. [DOI]

4. Li-You W, Hong-Wei Z, Gang Z, Guo-Qiang W, Fan Y (2017). Treatment of soft tissue defects in the heels of children in an emergency setting. J Pediatr Orthop B 26(2):152-8. [DOI]

5. Talukdar A, Yadav J, Purkayastha J, Pegu N, Singh PR, Kodali RK, et al.
Reverse sural flap - A feasible option for oncological defects of the lower extremity, ankle, and foot: Our experience from Northeast India. South Asian J Cancer. 2019; 8(4): 255-7. [DOI]

6. Follmar KE BA, Baumeister SP, et al. The distally based sural flap. Plast Reconstr Surg. 2007;119:138e-148e. [DOI]

7. Nakajima H IN, Fukuzumi S, Minabe T, Fukui Y, Miyasaka T, Kodama T, Aiso S, Fujino Tet al: Accompanying arteries of the lesser saphenous vein and sural nerve: anatomic study and its clinical applications. Plast Reconstr Surg. 1999, 103 (1): 104-20. [DOI]

8. Costa-Ferreira A RJ, Pinho C, Martins A, Amarante J. The distally based island superficial sural artery flap: clinical experience with 36 flaps. Ann Plast Surg. 2001;46(3):308-13. [DOI]

9. Hollier L SS, Babigumira E, Klebuc M. Versatility of the sural fasciocutane- 
ous flap in the coverage of lower extremity wounds. Plast Reconstr Surg. 2002;110(7):1673-9. [DOI]

10. Price MF CP, Watterson PA, Lettieri S. Reverse sural artery flap: caveats for success. Ann Plast Surg. 2002;48(5):496-504. [DOI]

11. Touam C RP, Bhatia A, Oberlin C. Comparative study of two series of distally based fasciocutaneous flaps for coverage of the lower one-fourth of the leg, the ankle, and the foot. Plast Reconstr Surg. 2001;107(2):383-92. [DOI]

12. Sugg KB ST, Concannon MJ, Cederna PS, Brown DL. The Reverse Superficial Sural Artery Flap Revisited for Complex Lower Extremity and Foot Reconstruction. Plast Reconstr Surg Glob Open. 2015;3(9):e519. [DOI]

13. Tsai J LH, Wang PF, Chen CT, Lin CH. Increasing the success of reverse sural flap from proximal part of posterior calf for traumatic foot and ankle reconstruction: patient selection and surgical refinement. Microsurgery. 2013;33(5):342-9. [DOI]
14. Wong CH, Tan BK. Maximizing the reliability and safety of the distally based sural artery flap. J Reconstr Microsurg. 2008;24:589-94. [DOI]

15. Jeng, SF, Wei, FC, Kuo, YR. Salvage of the distal foot using the distally based sural island flap. Ann. Plast. Surg. 43:499, 1999. [DOI]

16. Korompilias A GI, Korompilia M, Kosmas D, Kostas-Agnantis I. Reverse sural artery flap: a reliable alternative for foot and ankle soft tissue reconstruction. Eur J Orthop Surg Traumatol. 2019;29(2):367-72. [DOI]

17. Larrañaga JJ, Picco PI, Yanzon A, Figari M. Reconstruction of hind and midfoot defects after melanoma resection using the reverse sural flap: A case series. Surg J (N Y) 2017;3:e124-7. [DOI]

18. Al-Qattan MM.The reverse sural artery fasciomusculocutaneous fap for small lower-limb defects: the use of the gastrocnemius muscle cuf as a plug for small bony defects following debridement of infected/necrotic bone. Ann Plast Surg.2007;59(3):307-10. [DOI] 